\title{
Postcolonial Uncanny Narrative in Heart of Darkness
}

\author{
Yang Yang \\ School of Foreign Languages and Literatures, Sichuan University, Chengdu 610000, China. \\ 982501240@qq.com
}

\begin{abstract}
In the postcolonial context of Heart of Darkness, abject is the result of westerners' binary opposition to non-westerners and also the cause of their colonial career. Western civilization is full of the abject discourse about non-west and barbarism. Since the abject is part of or the result of those who abject. When civilization comes across barbarism, the former will have uncanny response. In Heart of Darkness, the horror of Marlow towards the African continent and the Africans is the uncanny return in the abject discourse, which inspires his rethinking about civilization and his self. Kurtz's yell before death is his reaction to the cruel ivory transaction and colonial actions in Africa, which forms the deconstruction of western civilization.
\end{abstract}

Keywords: Uncanny, abject, heart of darkness, postcolonial, strange self.

\section{Introduction}

Heart of Darkness is a famous novel of Joseph Conrad, which has combined the British Empire's colonial domination in Africa and Joseph Conrad's own foreign traveling experience. The novel is full of Conrad's thinking about the relationship between the west and the non-west and that between civilization and barbarism. The essay will discuss about the uncanny construction and deconstruction of western colonization. Such kind of interpretation will help readers see clearly the psychological mechanism of the narrative of the literary work against the post-colonial context and understand the other issue in the globalized world.

\section{The Definition of Uncanny and the Introduction to Abject Theory}

The word "uncanny" is translated from the German word "unheimlich", meaning "non-home, unfamiliar, uncontrolled, discomforting, and thrilling". The word "uncanny" is used to describe people's feelings about something strange but familiar. The uncanny feeling has been discussed by Sigmund Freud. In Das Unheimlice, he defines "uncanny" as the recurring of the repressed or repetitive desire. Some sudden fear is hard to describe and strange. However, it unamends is not causeless. The fear can be traced to some stage in the psychological development of a person [1]. Therefore, the strangeness is familiar to us.

The theory of abjection was first proposed by Julia Kristina. The word "abject" means something unclean, unhealthy or threatening. By combining Alcan's psychoanalysis theory, semiotics and female criticism, she formed her own feminine theory and abject theory. According to her view, "the most primitive reprimand comes from the abjection of the mother body of the real order. Only by carrying out the repulsion of the mother body in the real order can the individual enter the symbolic world smoothly." [2] The Father in the symbolic order represents order, power and authority. It is through identifying with and surrendering to the Father that an individual is accepted in the society. After that, Kristina developed the concept "uncanny" into "something that is excluded by social reason, which exists between the object and the subject." [3] It is not the uncleanness or unhealthiness that causes repulsion. From a macro perspective, the abjection is the response that people have when they are trying to preserve the boundaries between nature and society, barbarism and civilization.

If we put the concepts of uncanny and abject theory into the interpretation of post-colonial literary works, we will get some inspiration about how the colonized is shaped as the abject other and how it threatens the wholeness of the self and civilization of the colonizer. I will interpret the construction and deconstruction of the uncanny in Heart of Darkness through Marlow's and Kurtz's journeys into and out of Africa. 


\section{Into Africa: The Construction of Uncanny Experience}

Marlow was ordered to bring sick Kurtz to return to England. In the process of getting closer to the African continent, he encountered African barbarism and the African natives, which constituted his construction of uncanny fear against European civilization and the integrity of himself.

Along the upstream Nile River, Marlow looked at the landscape outside the ship. In his view, the African jungle is full of barbarians who feed on human beings and the thick jungle is as unfathomable as the indigenous blacks. Because it is unknown, it is full of mystique. It is this contradiction that makes Marlow have a strong desire to explore the land. This jungle is unintelligible and strange to Marlow, but it also makes him feel familiar. Because the African continent reminded him that ancient England had been a dark continent that could not be touched before it was invaded by Rome. "This was once one of the many dark places on the earth." [4] The African continent is like the predecessor of Britain.

In the geographical aspect, the African continent is now as green as it was in ancient times. In the evolution of civilization, Africa is one of the birthplaces of ancient civilization and the ancestor of mankind. It symbolizes the early stage of civilization full of barbarity, superstition and cannibalism. The affinity of geography and civilization makes Marlow feel both strange and familiar to the continent. Africa is Britain that has not been civilized. Marlow was full of fear in the face of the deep and bottomless jungle. Therefore, he lamented that the land was unearthly, but at the same time it was undeniable that the African continent and the primitive Britain had a kinship.

The specious relationship between the African continent and the primitive Britain prompted Marlow to question the continuity of civilization and makes him come cross unmanliness. The encounter with African natives in the jungle makes him question the ontology of human beings. In the description of the novel, these natives do not look like human beings. They are a pile of "black shapes. They are curled up, flat, or sitting under trees, leaning on the tree stump, close to the earth, half of the body on the ground, and half buried under the shadow under the tree. Live in pain and despair." [5] In the description, the natives often squatted on the ground or leaned on a tree. They seemed to have a close relationship with the earth. Reads cannot but think of human beings' evolution from creeping to erect walking. The western whites have walked upright and reclaimed civilization from the earth long time ago while these natives are still attached to the earth. Even a standing man is an untamed or independent personality.

Besides, the brief description of the blacks and that of the whites form a strong contrast. The whites are described as "unexpectedly elegant". Marlow once saw a white man on the African continent. He "has a pair of collars, a pair of white cuffs, and a light Alpaca coat, a white pair of trousers, a clean tie, and shiny leather shoes." [6] It can be seen that the natives do not have their own personal characteristics. African black people are alienated here. They give people the image that they belong to the land. Therefore, Marlow exclaimed, "this land is weird and terrible, the Africans living on the land, no, they are not inhuman. You know. But this is also the most frightening point, that is, the suspicion of them will gradually lead to the result. They are inhuman and barbaric. They howled, circled, making a terrible facial expression. But what makes you tremble is this kind of thinking about their human nature and the fact that you have had affinity with them long ago." [7]

From the above analysis, it can be seen that the construction of the uncanny experience of Marlow has embodied the cracks of the subjectivity of himself and the civilization of the west.

\section{Out of Africa: The Deconstruction of Uncanny Experience}

Kurtz goes further into the African continent. He is deeply involved in the cruel colonial cause and thus experiences the uncanniness of barbarism and pseudo civilization.

Because of his great contribution to European civilization, Kurtz was described as an emissary of civilization and a representative of European civilization. He came to Africa to create "boundless practical benefits" for the Africans. Kurtz came to Africa to "enlighten" the native people, but in his report to "the European Association for Barbaric Customs", he mentioned "eradicating all the barbarians". [8] The Western civilization represented by Kurtz is false, because their aim is 
contradictory to their real behavior. The huge economic benefits brought by ivory trading are the driving forces that really attract Kurtz and countless. Europeans just brought pseudo civilization to Africa continent and they take "opening the Continent to civilization" as the excuse to promote the economic power of their own countries. Pseudo civilization is like civilization, but it is not civilization. However, the role played by pseudo civilization in the historical process of European civilization cannot be underestimated. The fruits of European industrial civilization are not separated from the raw materials from the African continent and the demand for goods from the continent. Africa's raw materials including ivory are shipped to Europe in bulk. In Africa, labor is squeezed as much as possible while African are weakened by disease and hunger. The natives sit on the ground with no personal characteristics and the hands that grab for food are the best proof. Europe's pseudo civilization is part of the European civilization, but it is not a civilization. Nevertheless, it is a part that western civilization history tries to avoid mentioning.

In the description by all white men that Marlow met, Kurtz was portrayed as a first-class agent. He was so outstanding. He had a great future and could be an important figure in the company's management level but there is not much information about how Kurtz gained the reputation. In fact, he intimidated the natives in Africa by violence. The rows of skeletons in front of his house are the signals that he sent to the surrounding natives. The scary skulls on the branch could only be seen in the place where the cannibals live, but now they appear in front of a white man's house. The fracture of civilization and pseudo civilization is obvious. On the one hand, the atrocities of pseudo civilization are manifested in Kurtz's cruel treatment of the native people; on the other hand, it dissimilates Kurtz himself. Kurtz used the mystical conquest and the "integration" strategy to win the identification from the local people, "He was not afraid of these native people. The natives were not moving, until Kurtz gave orders that they began to surround Kurtz's house and every tribe leader crawled every day to see him." [9] All of a sudden, Kurtz is portrayed as the head of cannibal tribes. Marlow was amazed at the scene. "I don't want to know the ritual of these natives crawling to Kurtz, because I can't bear the details more than the skulls outside his window. This is just a scene full of barbaric things, but I seem to be exiled to a region full of fear and no light. In that case, pure barbarism has become a positive belief." [10] From this psychological description, compared to the shocking visual impact of the skulls outside Kurtz's house, Kurtz's identification with the natives is more shocking.

Kurtz's final cry before death "horror, horror" can be understood as Kurtz's fear for pseudo civilization and the result of his assimilation into barbarism.

\section{Summary}

The journey of Marlow into Africa and that of Kurtz out of Africa have shown clearly the construction and deconstruction of the uncanny colonial experience. It has deconstructed the white westerner's colonization over the African continent. As international interaction becomes more and more frequent, it is neceaasary to treat the other equally. When we treat other people as the other, we have already become the other in their eyes.

\section{References}

[1]. Freud, Sigmund. The Pelican Freud Library. Penguin Books, 1985, p. 340.

[2]. Ting, Luo. "Kristeva's Power Discourse and Literary Expression about Maternity and Abject". Foreign Literatures Quarterly. Vol. 4 (2003) No.1, p.3-9.

[3]. Childers, Joseph. The Columbia Dictionary of Modern Literary and Cultural Criticism. Columbia University Press, 1995, p. 308.

[4]. Conrad, Joseph. Heart of Darkness. Bedford Press, 1996, p.19.

[5]. Conrad, Joseph. Heart of Darkness. Bedford Press, 1996, p.31.

[6]. Conrad, Joseph. Heart of Darkness. Bedford Press, 1996, p.32. 
[7]. Conrad, Joseph. Heart of Darkness. Bedford Press, 1996, p.51.

[8]. Conrad, Joseph. Heart of Darkness. Bedford Press, 1996, p.66.

[9]. Conrad, Joseph. Heart of Darkness. Bedford Press, 1996, p.74.

[10]. Conrad, Joseph. Heart of Darkness. Bedford Press, 1996, p.75. 